Nigerian Journal of Technology (NIJOTECH)

Vol. 33. No. 3, July 2014, pp. $304-317$

Copyright@ Faculty of Engineering,

University of Nigeria, Nsukka, ISSN: $1115-8443$

www.nijotech.com

http://dx.doi.org/10.4314/njt.v33i3.7

\title{
SPATIAL SCHEME FOR GROUNDWATER FLOW AND PHYSICAL PROPERTIES DISTRIBUTION IN ILARO, SOUTHWESTERN NIGERIA
}

\author{
N. O. Adebisi1, ${ }^{*}$, A. A. Omitogun ${ }^{2}$ and A. A. Koya ${ }^{3}$ \\ 1,3 Department of Earth Sciences, Olabisi Onabanjo University, Ago IWOYe, Ogun State, NigERIA. \\ 2 Department of Geology, FACUlty of SCIEnCE, University of IbAdAn, Oyo State, NIGERIA. \\ E-mail addresses: 1noadebisi@yahoo.com,2ayomitogun@yahoo.com, ${ }^{3}$ seunkoya1@gmail.com
}

\begin{abstract}
Spatial flow patterns and quality trends for groundwater in Southwestern Nigeria have been undertaken with inadequate depth of interpretation. In this study, the geographical locations of wells and respective elevation were recorded using a Global Positioning System (GPS). Well depth and water level measurements were also obtained using measuring tape. Electronic meters were employed to determine temperature, salinity, hydrogen ion concentration (pH), Total Dissolved Solids (TDS) and electrical conductivity of 109 raw water samples. Geographical Information System (GIS) softwares (Arc View 3.3 and Surfer 8) were employed in the spatial data analyses. Results show that the groundwater flows towards the Southwest and Lower Mission in the Northwest, Orita in the East and Orita-TREM in the West. The pH ranges from 6.5 to 9.5 while TDS varies between 4.81 and $483.55 \mathrm{mg} / \mathrm{l}$. The use GIS has proved to more precise in terms of positional accuracy, than the conventional map analysis
\end{abstract}

Keywords: GIS, spatial, groundwater, flow, quality

\section{INTRODUCTION}

Groundwater has a geographical context, therefore, a study of its quality and variation over an area is important; particularly in the context of dissolved minerals present in the aquifer material that accommodates it. The geological nature of an aquifer is a pointer to the chemical composition of the groundwater in it. Water is constantly in contact with the ground in which it stagnates or circulates, until an equilibrium develops between the composition of the aquifer material and the water [1].

Evaluation of flow system and quality assessment of natural groundwater for domestic purpose is no doubt essential to human existence. Hydrologic models of water quality have been developed with a focus on groundwater chemical constituents [2]. According to There have been adequate data to support trend analysis of groundwater quality in most parts of Southwestern Nigeria, however, the compilation of all available groundwater quality data has been undertaken with inadequate depth of interpretation [3]. The Geographical Information System (GIS) method of presenting groundwater quality data for decision support does not generate problems with spatial dimension. Hence, there is a need for a knowledge base to develop oriented planning with high positional accuracy, less laborious and timesaving computer-based tool. GIS is a computer-based tool critical to water resources management studies [4-6]. The equipment used to make measurements for a GIS can be far more precise than the machines used in conventional map analysis. The versatility of GIS to elucidate spatial variation in physical parameters, which are basic to water quality assessment, has not been exploited through a serious research.

Unlike maps, GIS has the advantage of communicating information on the status of groundwater quality to concerned user communities and policy makers [7]. These researchers agree that groundwater quality parameters that are often evaluated in physical analyses include TDS, electrical conductivity, salinity and temperature. The use of GIS in groundwater quality evaluation has become increasingly recognized as the development of groundwater studies continues to expand in Nigeria. Hydrologic models are useful to evaluate the chemistry of major ions and 
hydrogeochemical processes of groundwater [8]. The GIS technique helped in mapping the water quality index (WQI) in Kaltungo area of North-Eastern Nigeria. This research established the possible linkage of the WQI with GIS geo-data base as an indispensable tool for assessing and management of groundwater [9].

Description of the movement of water in the subsurface requires knowledge of well parameters, while the physical properties of groundwater are a direct expression of the aquifer material composition. Physical parameters such as total dissolved solids (TDS), specific electrical conductance, hydrogen ion concentration $(\mathrm{pH})$ and temperature are primary indicators to the characteristics of groundwater. Understanding the distribution of these properties is a key to understanding the patterns of groundwater quality. The aims of this study are to aid the use of GIS database in decision-making processes by modelling subsurface flow pattern, and to identify groundwater types through physical parameters in maps format. In this study, an advanced mapping technique is employed such that data were organized into a coherent and logical structure supported by a computing environment. The GIS, however, depicted two dimensional characteristics of the surface and ground water interaction, as well as the raster of the terrain and groundwater flow vectors in the area. The physical properties information points offered an opportunity to validate variation in groundwater quality, and check the consistency of the groundwater dataset.

\section{LOCATION AND HYDROGEOLOGY}

The study area is Ilaro; one of the major towns in Ogun state, South-Western part of Nigeria. As shown in Figure 1, it lies between latitudes $\mathrm{N}^{0} 6^{\circ} 52^{\prime}-\mathrm{N}_{0} 6^{\circ} 54^{\prime}$ and longitudes $\mathrm{E} 002^{\circ} 59^{\prime}-\mathrm{E} 003^{\circ} 01^{\prime}$ in the tropical region of Africa, and underlain by sedimentary rocks of the Dahomyean Miogeosynclinal Basin. The strata represented within the basin have a total thickness of about $3000 \mathrm{~m}$ and include Alluvial Sediments, Coastal Plain Sands, Illaro Formation, Ewekoro Formation and Abeokuta Formation, which directly overlies the Basement Complex in Abeokuta [10]. The basin covers much of the continental margin of the Gulf of Guinea, and extends from the Volta Delta in Ghana in the west to the Okitipupa Ridge in Nigeria. Figure 2 shows the surface water hydrology in dendritic pattern, which reflects the morphological feature of the terrain [11]. The aquifer materials for groundwater include sandstone, Arkoses, Shale, shelly shallow water limestone, unconsolidated sands and soft marine clays. As water flows through these sedimentary rocks, it is expected that the water reacts with the mineral make up of the rocks. Physical parameters such as TDS, specific electrical conductance and $\mathrm{pH}$ so far developed, would provide the basic quality information on the suitability and types of groundwater in the area. A final note on this concerns temperature, which has been assumed to be a function of depth of groundwater occurrence. This is important in the case of industrial users, and also for geothermal heating and cooling.

\section{METHOD OF STUDY}

The varied water level conditions and unregulated shallow groundwater development in the area are common challenges, which require investigation of the aquifer systems. A reconnaissance survey was conducted to locate and identify 109 wells for the research. In the field, geographical locations of wells and ground elevation values were determined with the aid of a Global Positioning System (GPS). This was to enable the development of a digital elevation model (DEM) from a topographic data base for the GIS. Well depth and water level measurements were also obtained using measuring tape with hook, line and sinker. Electronic meters, were employed through simple procedures to determine temperature, salinity, $\mathrm{pH}$, TDS and electrical conductivity of the native water samples immediately after collection. Arc View 3.3 was used to generate the 2D maps for the study area and for every measured water quality parameter, while Surfer 8 software was used to a generate the raster of groundwater flow vectors.

\section{DISCUSSION OF RESULTS}

\subsection{Flow System}

A presentation of the flow system is an important component of the surface water - groundwater interaction [12]. Figure 3 shows a two-dimensional topographic coverage from which streams in the area receive runoff and recharge the groundwater. Using maps of the study area, surface water drainage system, well locations and water table contours, the GIS produced a two dimensional map overlay that ranks the groundwater with its relative sensitivity to supply from the surface water. 


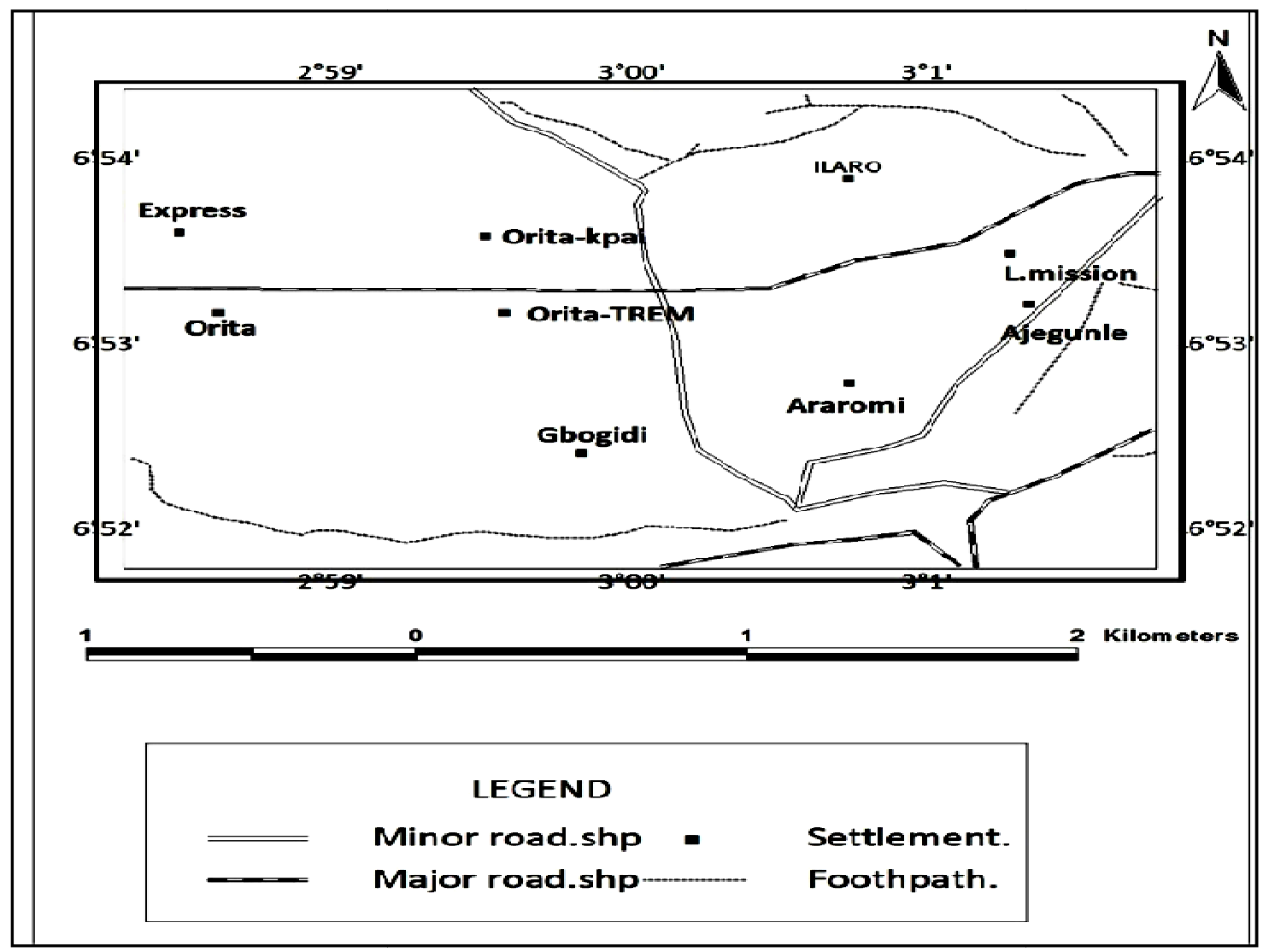

Figure:1. Map of the study area

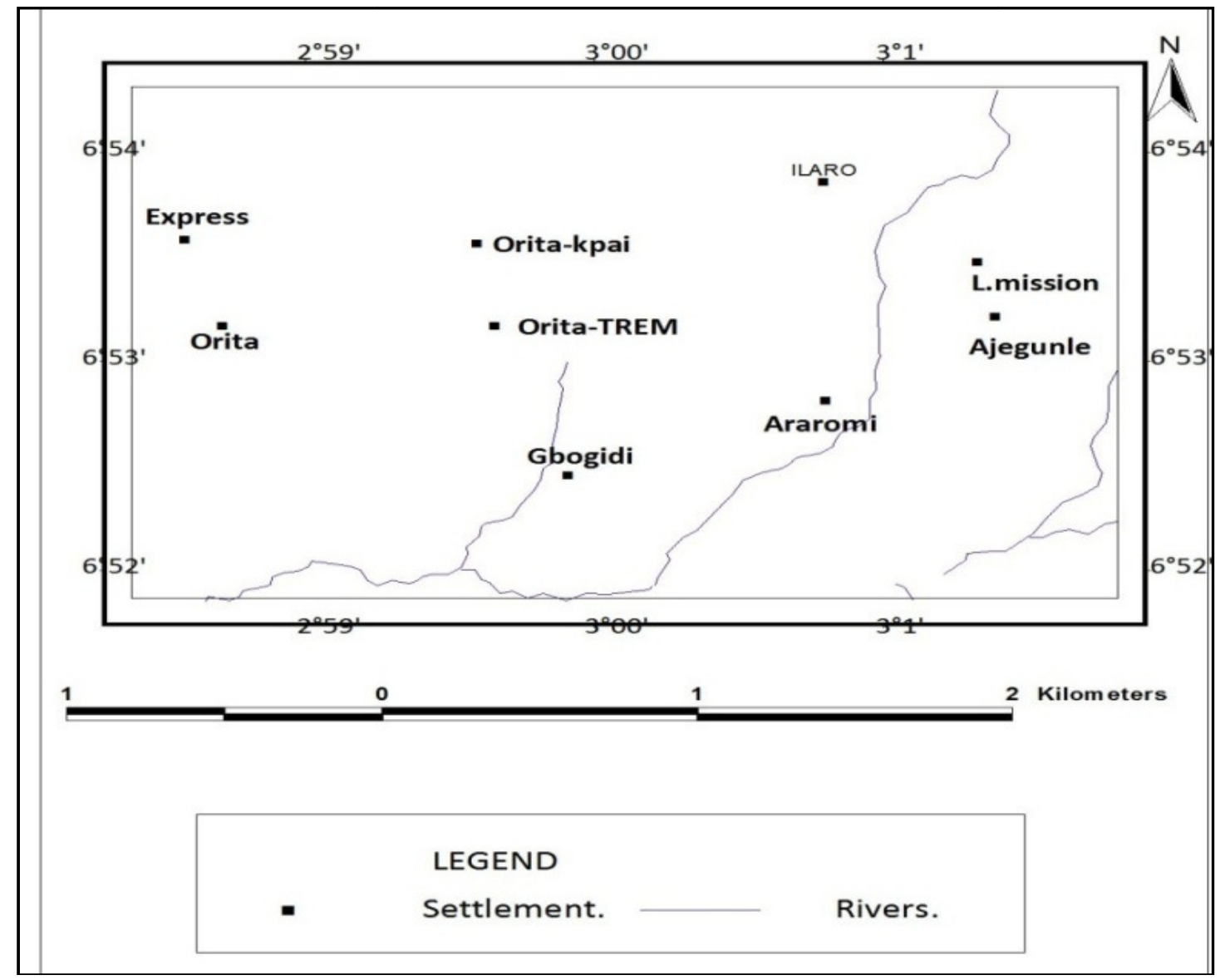

Figure:2. Map showing drainage pattern of the study area 


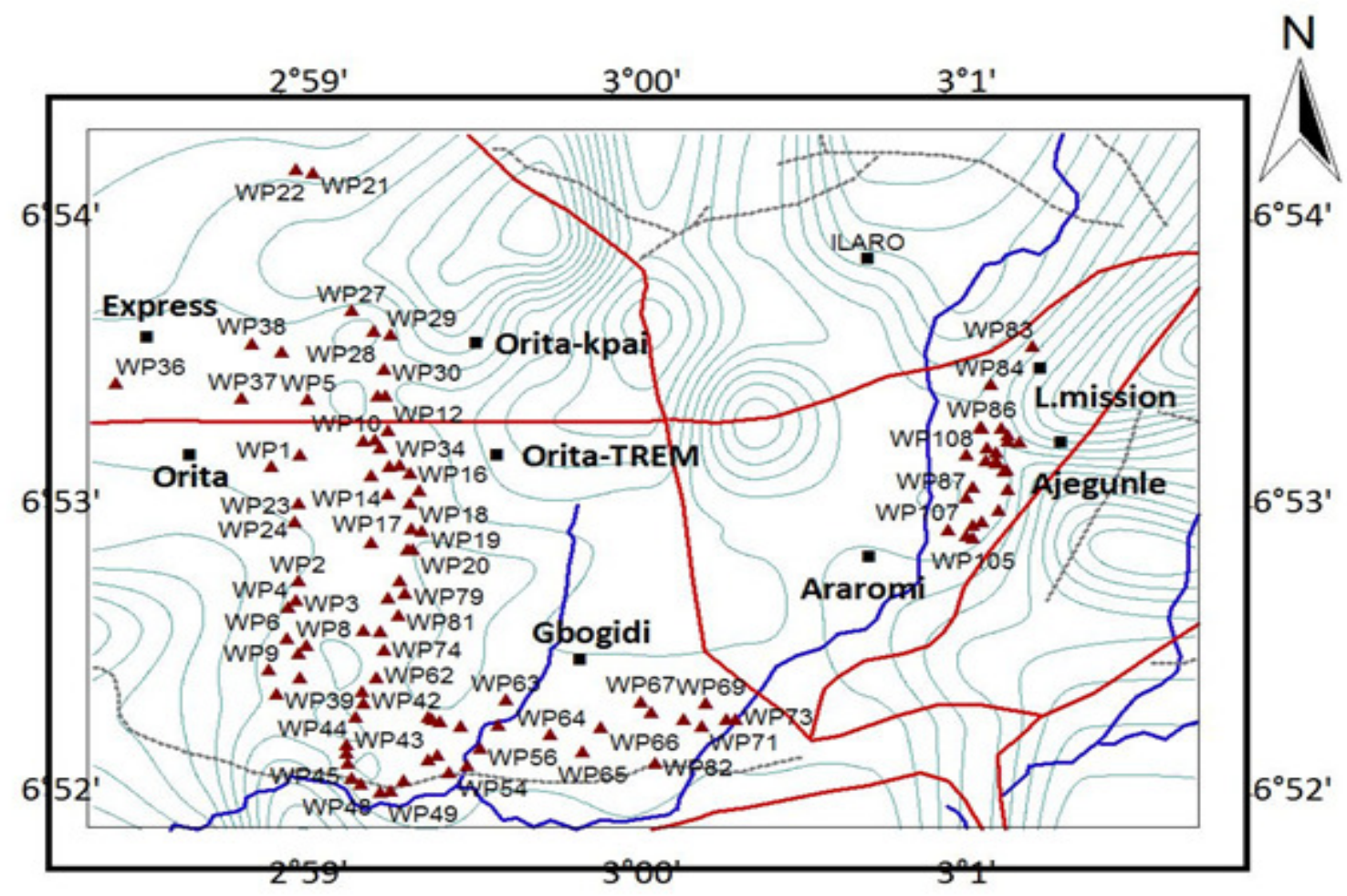

1 0

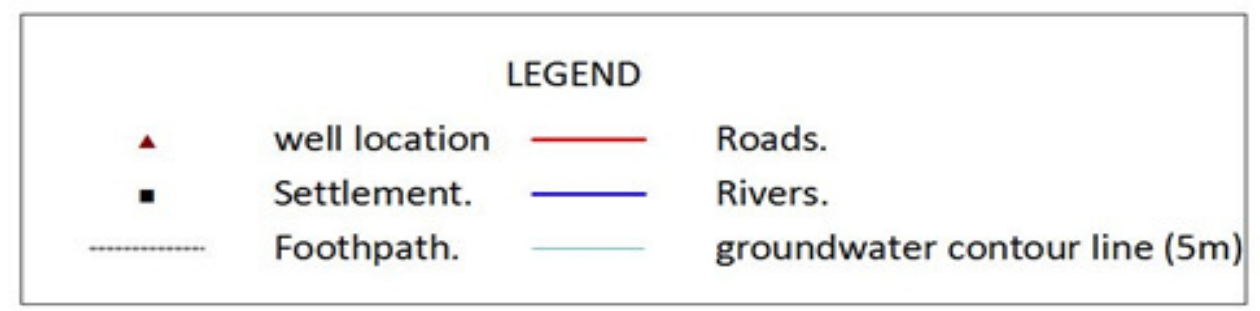

Figure:3. Map showing surface-groundwater interaction in the study area

The water table configuration is a direct expression of the groundwater flow pattern [12]. Convex contour lines in the northern and eastern parts of the study area are indicative of groundwater recharge locations. However, concave contour lines in the southwestern part of the area indicate locations of groundwater discharge into the surrounding zone. It is apparent that the drainage pattern of streams strongly controls recharge and discharge of groundwater in the area. For detailed description of topography, the digital elevation model (DEM) was used. Landform elements are best delineated using topographic attributes [13, 14]. Major topographical features recognized in the area are high lands, low lands, valleys and floodplains. The configuration of the land surface influences the expression of the subsurface. It follows that landform elements relate to hydrologic characteristics, and also influence groundwater flow. This brings about a more realistic analysis of the three-dimensional model with groundwater flow velocity and direction, as against the traditional two-dimensional static map. The subsurface drainage area shown in Figure 4, was analysed with the use of a DEM and a digital record of static water levels for well positions.

The subsurface flow system in the study area is expressed in conjunction with a three-dimensional closed system, containing the flow paths from various points at which water enters the aquifer to the topographically lower points where it leaves. The flow directions are depicted by the black arrows on the network, with the arrows pointing in the downstream directions. 

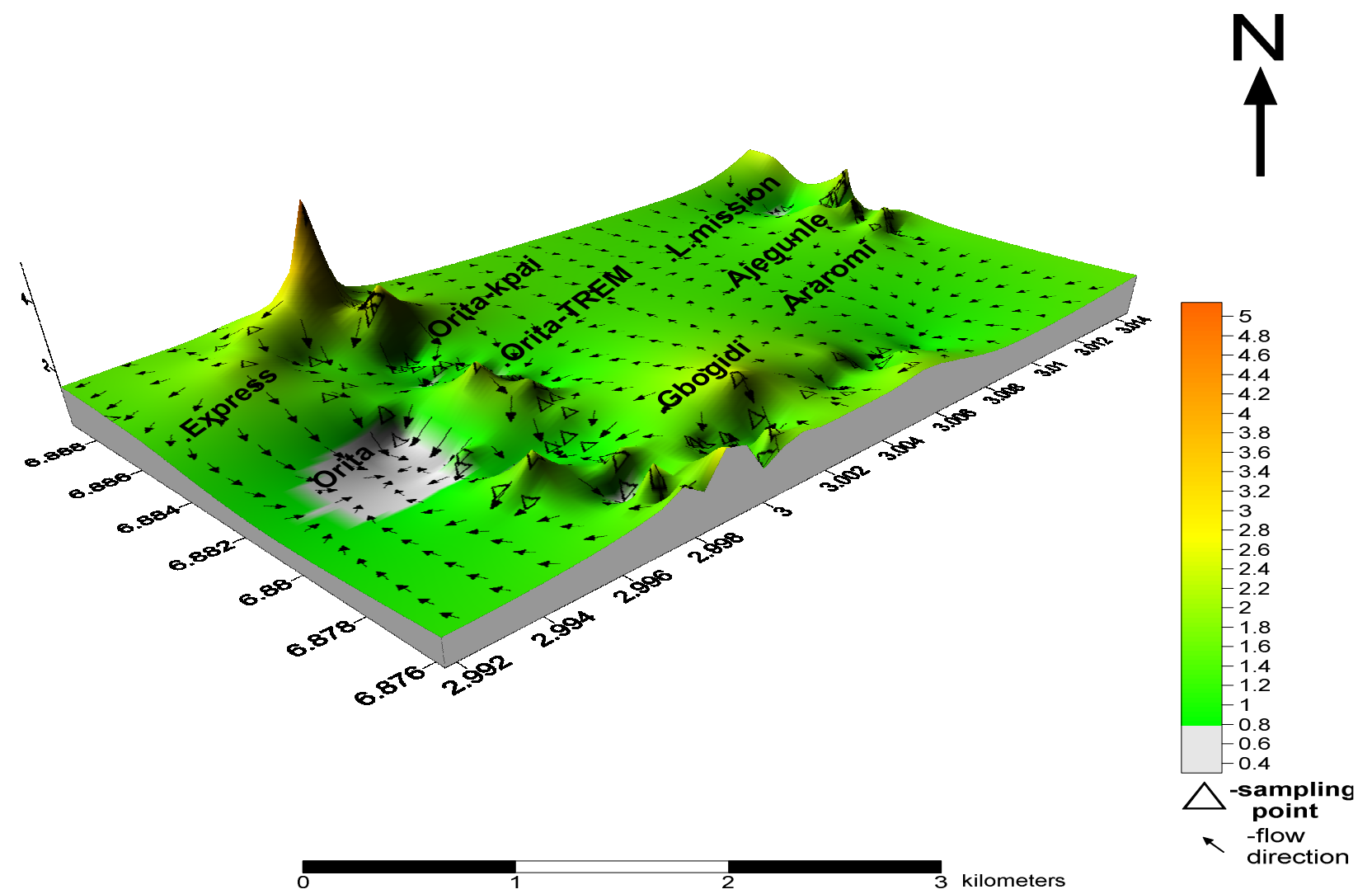

Figure:4. Terrain model and groundwater flow velocity / direction

The Darcy's law provides a valid description of the flow of groundwater in most naturally occurring hydrogeological conditions. Darcy's is a phenomenological derived constitutive equation that describes the flow of a fluid through a porous medium in relation to permeability coefficient $(\mathrm{K})$ within a cross sectional area (A) [15]. At constant elevation, the instantaneous discharge rate through a porous medium $(Q)$, the viscosity of the fluid $(\mu)$ and the pressure $\left(\mathrm{P}_{\mathrm{a}}-\mathrm{P}_{\mathrm{b}}\right)$ drop over a given distance $(\mathrm{L})$ is expressed in equation 1 below.

$$
\mathrm{Q}=-\frac{K A}{\mu} \frac{(P a-P b)}{L}
$$

Gravity is the major driving force for subsurface flow, and thus groundwater is always moving from areas of higher pressure gradient to lower pressure gradient [16]. The dataset is consistent with the raster of the groundwater flow vectors. The groundwater flow directions are complex, indicative of complicated geological conditions. The groundwater flows towards Ajegunle, Orita-kpai and Express in the Southwest, Gbogidi and Lower Mission in the Northwest, Orita in the East and Orita-TREM in the West. The groundwater flow pattern in the area was generated primarily from the distribution of heads within the hydrologic system. From figure 4 , it can be observed that the distribution of heads is controlled by the relative topographic elevations; the location and effectiveness of recharge /discharge areas of the aquifer system.

\section{THE WATER QUALITY PATTERN}

\subsection{Temperature}

The temperature of groundwater is generally equal to the mean air temperature above the land surface. The temperature distribution of water from various wells in the area was numerically overlapping. Relatively high temperature waters are from wells in the eastern part, while relatively low temperature waters are from wells in the western part of the study area. The temperature of the ground water in the area ranges between $29.06^{\circ} \mathrm{C}$ and $20.63^{\circ} \mathrm{C}$. The rate of increase in groundwater temperature is usually attributed to depth of its occurrence $[17,18]$. Temperature is an important factor in determining allowable limits for other parameters. 


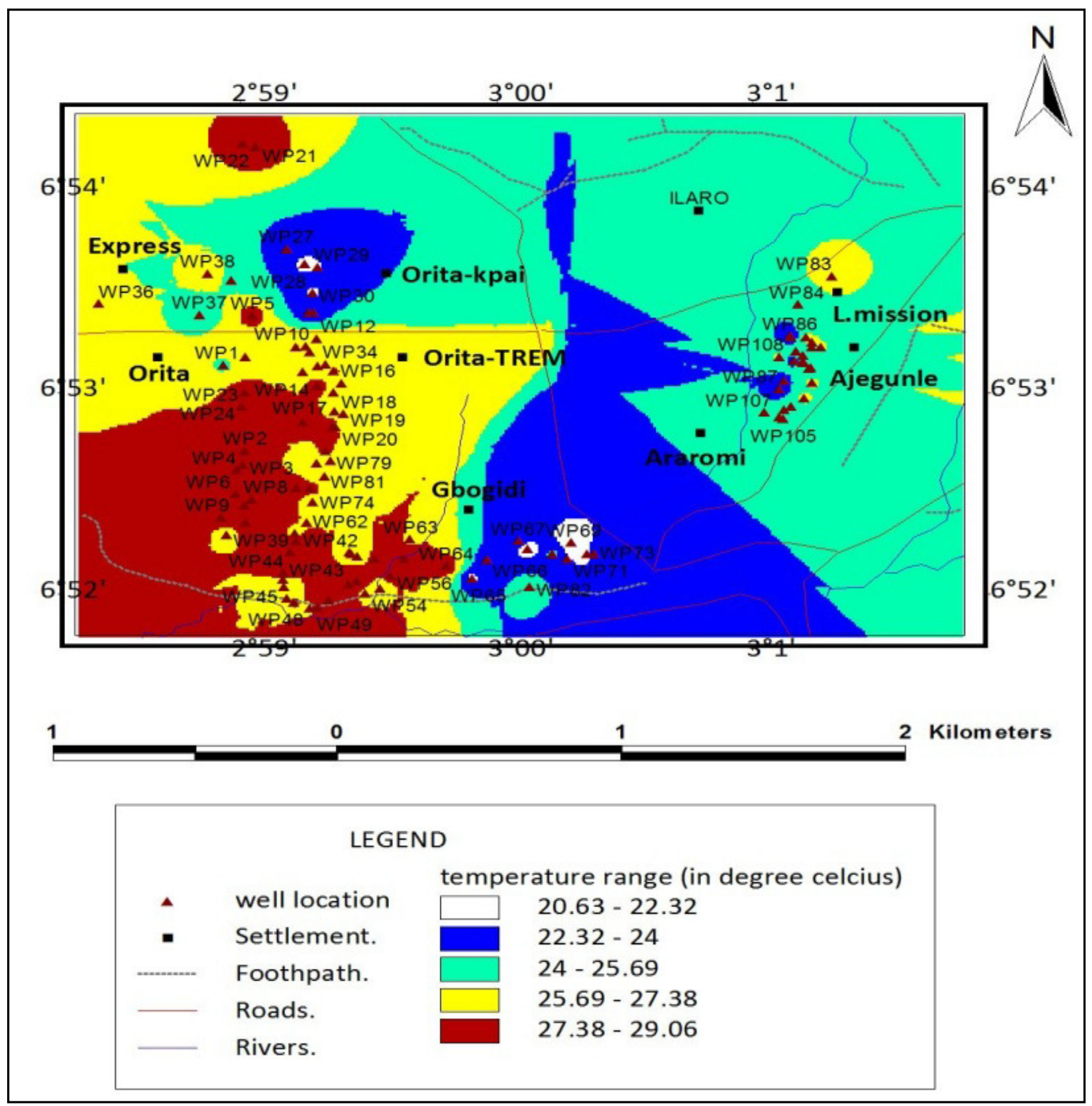

Figure:5. Spatial variation in groundwater temperature

\subsection{Dissolved Salts}

Salinity is a measure of the total amount of salts dissolved in groundwater. It is a valuable parameter among indicators of groundwater's suitability for various uses. Figure 4 is a map showing the generalized zones of groundwater salinity in the area. Salinity of the studied groundwater was very low. It ranged between 0 and $0.01 \mathrm{mg} / \mathrm{l}$, which is very typical of fresh water. Water having salinity less than $500 \mathrm{mg} / \mathrm{l}$ is very suitable for most purposes [24]. The salinity levels in the groundwater could increase through dissolution of the aquifer materials. However, the low salinity observed would have resulted from water flowing in the laterised aquifer above the limestone. Such water flowed over the quartzitic aquifer material, which does not contribute ions into dissolved salts in the water. The reverse would have been the case if the water was flowing over limestone which dissolves easily to induce a higher salinity than water flowing over quartz. 


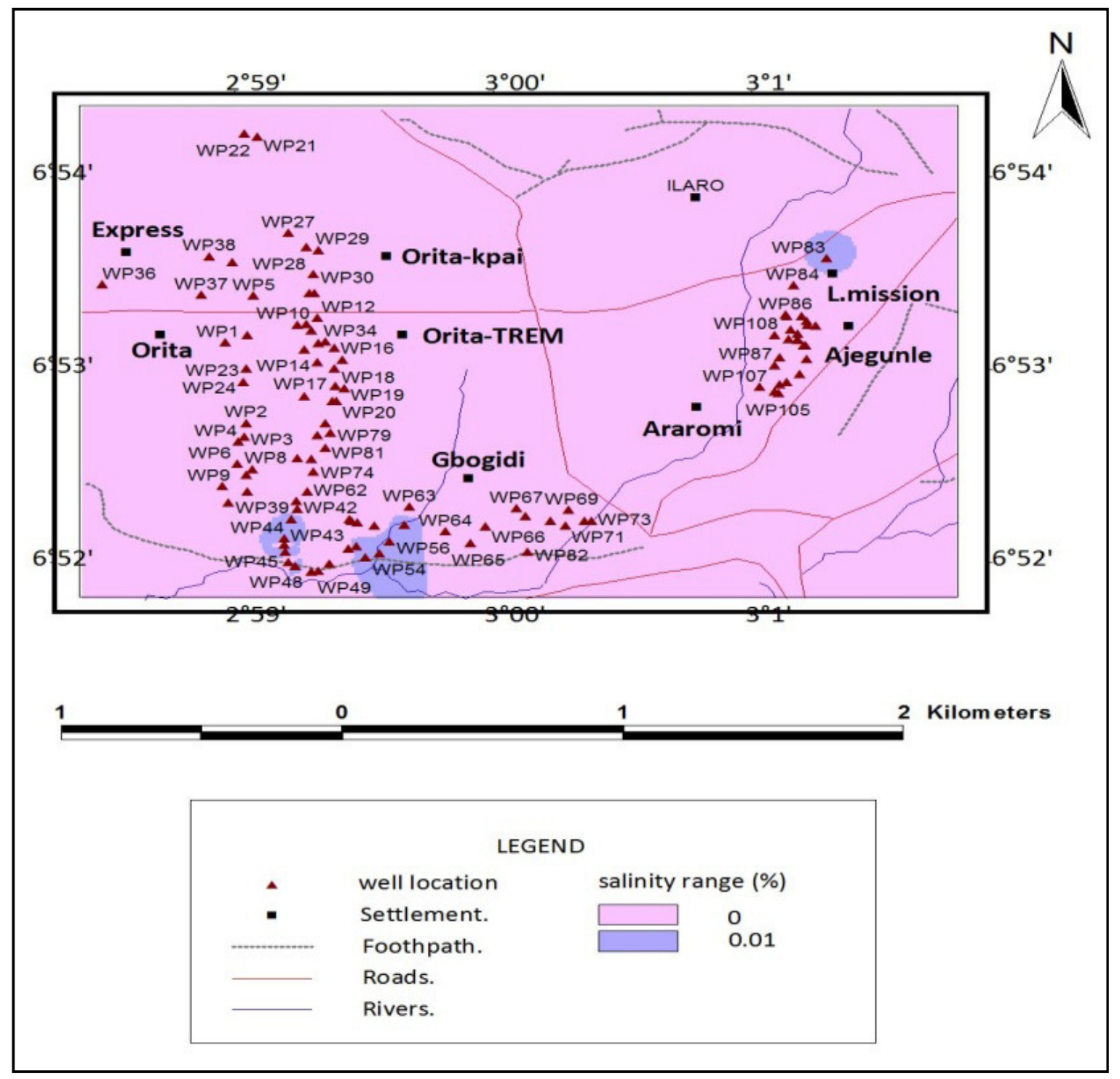

Figure:6. Spatial variation in groundwater dissolved salts

\subsection{Hydrogen Ion Concentration $(\mathrm{pH})$}

The concentration of hydrogen ions is measured by $\mathrm{pH}$, and is equal to the $-\log \left[\mathrm{H}^{+}\right]$. The $\mathrm{pH}$ of groundwater controls which cations, anions, gases and solids dissolve into groundwater and which exit from groundwater. The $\mathrm{pH}$ scale ranges from 0 to 14 . A pH of 7 is indicative of neutral water; if greater than 7 , the water is basic; and less than 7, the water is acidic. The WHO [19] $\mathrm{pH}$ range standard of groundwater for permissible limit is 6.5-9.5.

In the study area the measured $\mathrm{pH}$ values of groundwater conforms to the limits acceptable for drinking purpose. However, three classes of $\mathrm{pH}$ are represented in the groundwater quality pattern of the study area. Groundwater with pH range of $6.14-7.18$ dominates the area, especially in the western part of the study area. There was a problem of low $\mathrm{pH}$, or acidic water. The occurrence of groundwater with $\mathrm{pH}$ range of $4.8-6.14$ in the eastern part of the study area represents contamination from anthropogenic sources from local mining activity of limestone in the area.

Considering the influences of the lower limestone and the upper lateritic aquifers in the area, the $\mathrm{pH}$ of the groundwater is expected to reflect the type of carbonate or silicate respectively that occurs in the solution. Predictably, in acidic solutions, $\mathrm{H}_{2} \mathrm{CO}_{3}$ is the dominant carbonate salt in the limestone aquifer, followed by $\mathrm{HCO}_{3}{ }^{-}$, then $\mathrm{CO}_{3}{ }^{2-}$ ions as solutions become more basic. A similar progression is expected of silicates in the lateritic overburden from $\mathrm{H}_{2} \mathrm{SiO}_{3}$ to $\mathrm{HSiO}_{3}{ }^{-}$to $\mathrm{SiO}_{2}{ }^{-}$as solutions change from acidic to basic. The carbonate and silicate ions serve as strong bases as strong acids are not common in natural groundwater. Consequently, as groundwater flows 
through the aquifers, it dissolves more carbonate than silicate minerals thereby increasing the alkalinity and the $\mathrm{pH}$.

\subsection{Total Dissolved Solids (TDS)}

The total dissolved solids (TDS) are a good indicator of the mineralized character of groundwater. The groundwater in the study area has concentrations of various dissolved solids ranging between 4.81 and $183.55 \mathrm{mg} / \mathrm{l}$. This is less than $500 \mathrm{mg} / \mathrm{l}$, which is the limit indicative of suitability for domestic and industrial uses. The spatial variation map revealed that groundwater of TDS range of 4.81 - 40.56 dominated the study area. However, relatively high TDS groundwater is uncommon except in well No.63 at Lower mission area. The laterised overburden would have added dissolved constituents such as iron compounds to groundwater, as well as calcium, magnesium and bicarbonate from the limestone aquifer. These naturally-occurring constituents can affect taste and its use for various purposes. Carbonates from the limestone aquifer lead to high total dissolved solids, which are often indicative of characteristics such as hardness.

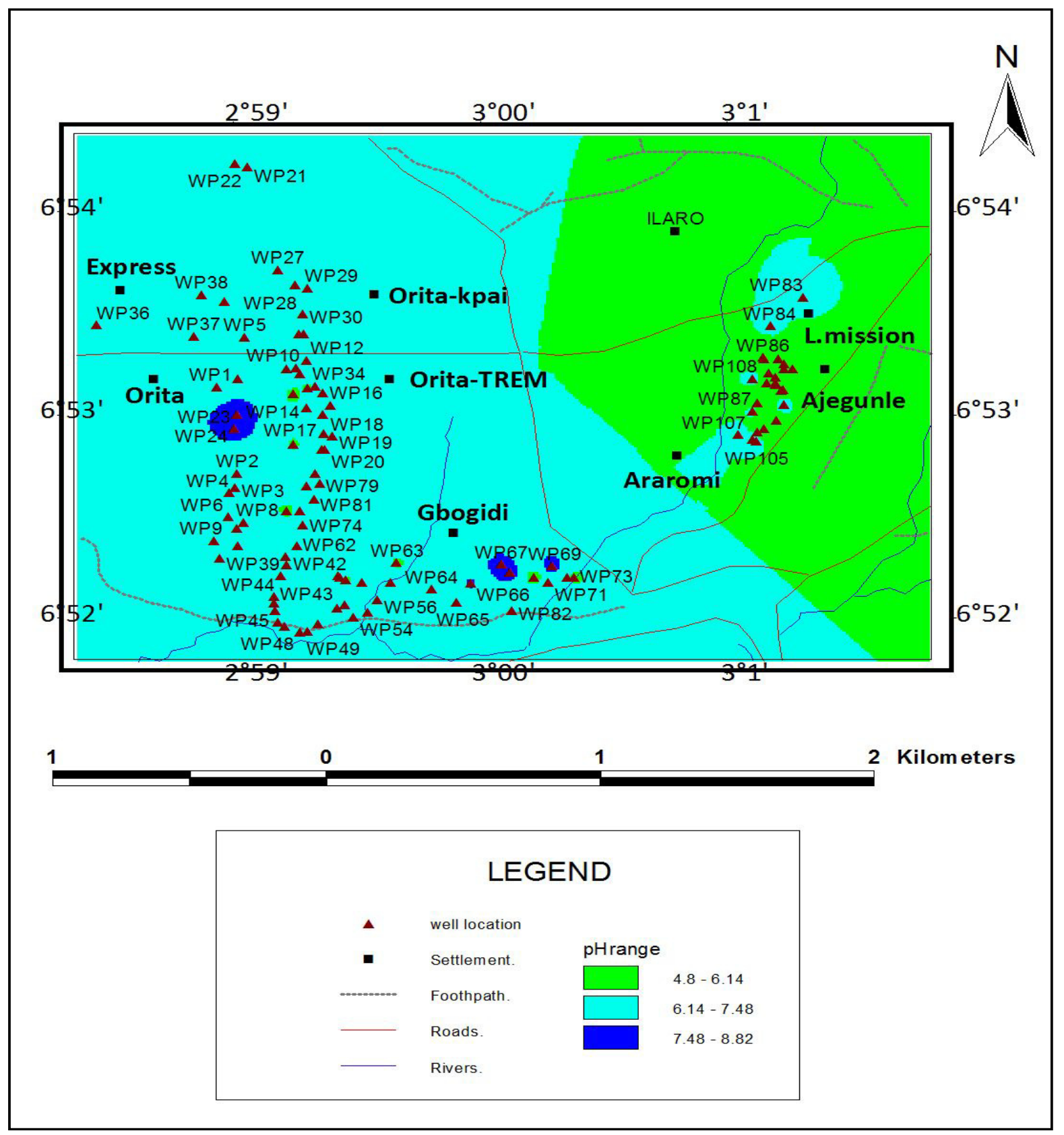

Figure:7. Spatial variation in groundwater $\mathrm{pH}$ 


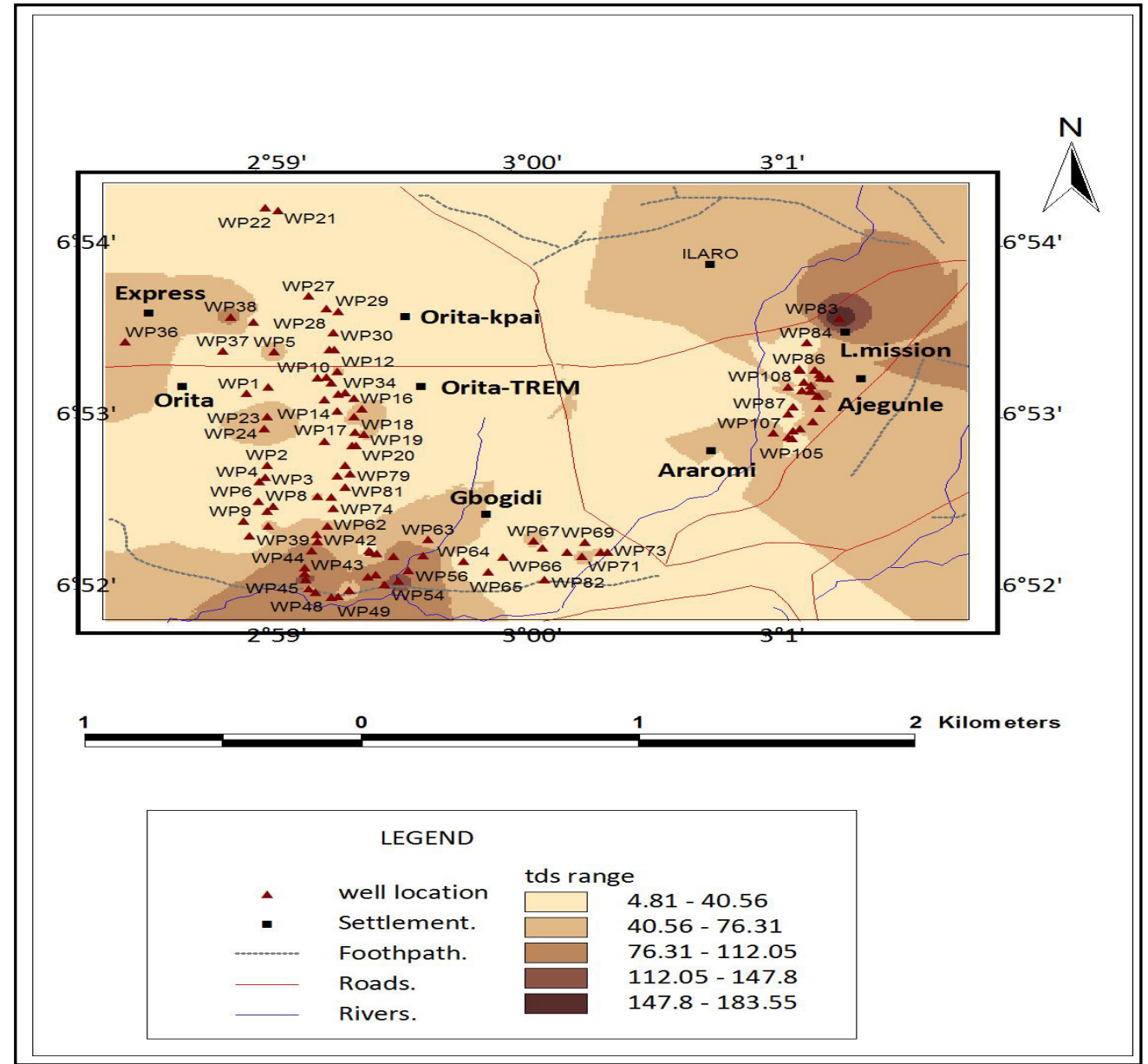

Figure:8. Spatial variation in groundwater TDS

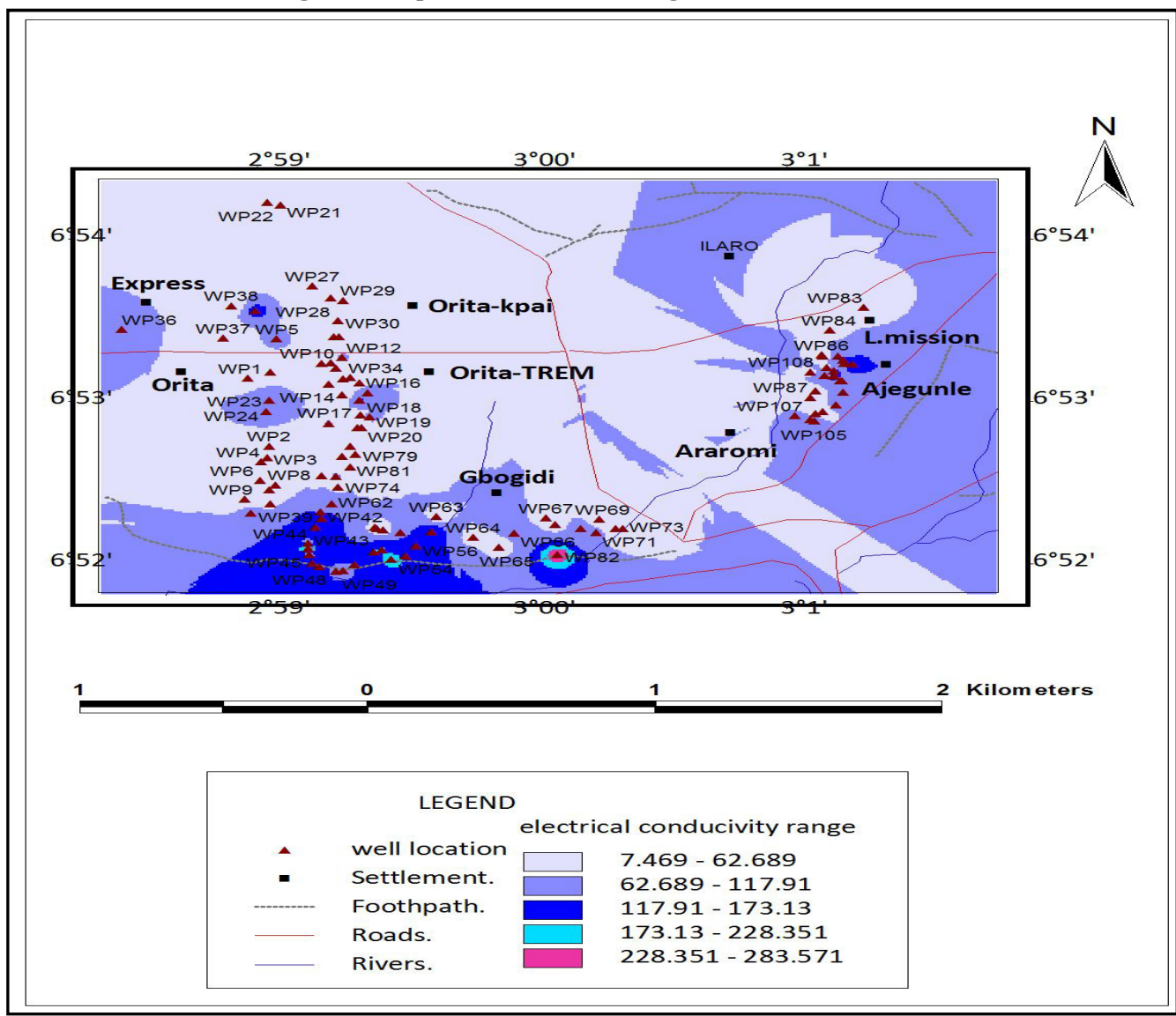

Figure:9. Spatial variation in groundwater specific electrical conductance 


\subsection{Electrical Conductivity}

The specific electrical conductance is another important physical property useful in defining groundwater quality. This is indicative of dissolved ion concentrations in the water, which in turn reflects groundwater input, catchment geology, or diverse human impacts. Relatively low conductivity water dominates the area. One distinctive case noted in the Southern part of the study area where the electrical conductivity was high in well point (WP) 82 , could be due to groundwater reacting with the minerals in the aquifer material. In the study area, five classes of conductivity were revealed as in the case of TDS. It is no doubt that the number of charged ions in groundwater increase with increase in the electrical conductivity [20]. This is true as strong positive association has been established between TDS and electrical conductivity of groundwater. The specific electrical conductance of groundwater from most of the wells in the area satisfied the $1200 \mu \mathrm{S} / \mathrm{cm}$ WHO [18] requirement for domestic purposes.

\section{CONCLUSIONS}

The Geographical Information Systems (GIS) facilitated processing of geo-referenced data to expound groundwater flow, and quality distribution based on physical properties in an area underlain by sedimentary rocks. In the utilization of GIS, information and the related landscape element are represented in the form of proper maps, which give better insight so that development and management strategies could be derived. From the output, elevations and static water level contours reveal good relationship between spot heights and groundwater flow directions depicting areas of recharge from, and discharge into the surrounding zone. Temperature, salinity, TDS and specific electrical conductance values generally fall within the acceptable limits of the World Health Organisation for domestic purposes. Further testing is not recommended, as only water with a high TDS is indicative of elevated levels of ions that could pose a health concern. These include ions such as aluminium, arsenic, copper, lead, nitrate e.t.c. Since water is available in the subsurface and the Ilaro community uses it for sustenance, the GIS method of preparation of maps to express the records of the flow pattern with the influencing factors such as geology is the key to groundwater development oriented planning. It is apparent that geological conditions in the study area are complicated. The limestone of the Ilaro Formation which underlies the laterised overburden is bound to have contributed dissolved constituents such as calcium, magnesium and bicarbonate compounds to the groundwater. Therefore, the physical properties of water in the Ilaro aquifer system represent the net effect of the processes that have dissolved the chemical constituents. The initiative to employ a GIS approach to develop spatial information on groundwater in areas underlain by sedimentary rocks is strongly recommended.

\section{REFERENCES}

[1] Brakebill, J. W., (1994), Applications of a geographic information system in water-quality assessment of the Potomac River Basin study unit, National WaterQuality Assessment Program [abs.]: Abstract Booklet, Mid-Atlantic Highlands Area Environmental Monitoring and Assessment Conference, Hershey, Pennsylvania, February 23-25, pp. 63.

[2] Nwankwoala, H.O. and Udom, G.J. 2011. Studies on Major ion Chemistry and Hydrogeochemical Processes of Groundwater in Port Harcourt City, Southern- Nigeria. Journal of Spatial Hydrology, Vol. 11(1), pp.1-16.

[3] Ayedun, H., Oyede, R. T., Osinfade, B. G., Oguntade, B. K., Umar, B. F. and Abiaziem, C. V. 2012. Groundwater quality around new cement factory, Ibese, Ogun State, Southwest Nigeria. African Journal of Pure and Applied Chemistry Vol. 6(13), pp. 219-223

[4] Christophoridis, C., Bizani, E. and Fytianos, K. 2000. Environmental Quality Monitoring, Using GIS as a Tool of Visualization, Management and DecisionMaking: Applications Emerging from the EU Water Framework Directive EU 2000/60.

[5] Heywood, I., Cornelius, S., and Carver, S. 2006. An Introduction to Geographical Information Systems. Prentice Hall. 3rd edition.

[6] Michael A. N., Aslan, A. and Maureen I. N. 2013. Application of Geographic Information System (GIS) in sustainable groundwater development, Imo River Basin Nigeria. International Journal of Water Resources and Environmental Engineering. Vol. 56, pp. $310-320$.

[7] Leblanc, M., Leduc, C., Razack, M., Lemoalle, J., Dagorne, D. and Mofor, L. 2003. Applications of remote sensing and GIS for groundwater modelling of large semiarid areas: example of the Lake Chad Basin, Africa. In: Servat E, Najem W, Leduc C, Shakeel A (eds) Hydrology of Mediterranean and Semiarid 
Regions. IAHS Publ. 278, IAHS Press, Wallingford, UK., pp. 186-192.

[8] Nwankoala, H. 0. 2011.Coastal aquifers of Nigeria: An over view of its management and sustainability considerations. Journal of Applied Technology in Environmental Sanitation. 1, 4.pp. 371-380

[9] Abulhakeem, A., Ishaku, J. M. and Ahmed, A. S. 2011. Mapping of water quality index using GIS IN Kaltungo, Northeastern Nigeria. Journal of Environmental Sciences and Resource Management. Vol. 3, pp. 94 -106.

[10] Nton, M.E., 2001. Sedimentological and geochemical studies of rock units in the eastern Dahomey Basin, Southwestern Nigeria. Unpublished Ph.D thesis, University of Ibadan, pp. 315.

[11] Ladokun, L. L., Ajao, K. R. and Sule, B. F. 2013. Hydrokinetic Energy Conversion Systems: Prospects and Challenge in Nigerian Hydrological Setting. Nigerian Journal of Technology Vol. 32., No. 3, 538 549.

[12] Ngerebara, O.D and Nwankwoala, H.O 2008. Groundwater potentials in the offshore Niger Delta environment, Nigeria. Electronic Journal of Environmental Hydrology. 16, Paper 28, http//www.hydroweb.com

[13] Weibel, R. and Heller, M. 1991. Digital Terrain Modelling, in: Maguire, D.J., Goodchild, M.F., and Rhind, D.W. (eds.) Geographic Information Systems: Principles and Applications, Longman, London, pp. 269-297.

[14] Wood, J. 1996. The Geomorphological Characterization of Digital Elevation Models. Ph.D. dissertation, Department of Geography, University of Leicester, UK.

[15] Pant, L. M., Sushanta K. M. and Marc S. 2012. "Absolute permeability and Knudsen diffusivity measurements in PEMFC gas diffusion layers and micro porous layers". Journal of Power Sources. Vol. 206, $153-160$.

[16] Igboanugo, A. C and Chiejine CM, 2014, "Modeling of far-field mixing of indutrial effluent plume in ambient receiving water: The Ikpoba River hub example, Nigerian Journal of Technology, Vo. 22, No.2, April 2014, pp. 199 - 206.

[17] Lapham, W.W., 1989. Use of temperature profiles beneath streams to determine rates of vertical groundwater flow and vertical hydraulic conductivity. U.S. Geological Survey Water Supply Paper 2337.

[18] Miyakoshi, A., Uchida, Y., Sakura, Y. and Hayashi, T. 2003. Distribution of subsurface temperature in the Kanto Plain, Japan; estimation of regional groundwater flow system and surface warming. Physics and Chemistry of the Earth, Parts $A / B / C$. Vol. 28, Issues 9-11, pp. 467-475

[19] World Health Organization (WHO). 2004.Guidelines for Drinking-Water Quality (Third edition). 1. Recommendations. WHO, Switzerland.

[20] Adebisi, N.O. 2010 Shallow Well Parameters and Overall Groundwater Quality in Ago-Iwoye and its environs Southwestern. Nigeria. Science Focus. Vol. 15 , No.3, pp. $338-344$. 
APPENDIX

Records of hydrogeological data form llaro

\begin{tabular}{|c|c|c|c|c|c|c|c|c|c|c|c|c|c|c|c|}
\hline$S / N$ & LOCATION & LATITUDE & NORTHINGS & LONGITUDE & EASTINGS & $\begin{array}{l}\text { WELL } \\
\text { DEPTH } \\
(\mathrm{m})\end{array}$ & $\begin{array}{c}\text { WATER } \\
\text { LEVEL (m) }\end{array}$ & $\begin{array}{l}\text { WELL } \\
\text { HEAD } \\
(\mathrm{m})\end{array}$ & $\begin{array}{c}\text { CONDITION OF THE } \\
\text { WELL }\end{array}$ & COLOUR & $\begin{array}{c}\text { TEMPERATURE } \\
\left({ }^{\circ} \mathrm{C}\right)\end{array}$ & $\mathrm{PH}$ & TDS & $\begin{array}{c}\text { SALINITY } \\
(\%)\end{array}$ & $\begin{array}{c}\text { ELECTRICAL } \\
\text { CONDUCTIVITY }\end{array}$ \\
\hline 1 & $\overline{\text { ORITA }}$ & $06^{0} 53^{\prime} 04.9^{\prime \prime}$ & 6.88469 & $002^{0} 59^{\prime} 44.5^{\prime \prime}$ & 2.99569 & 25.95 & 1.45 & 24.5 & COVERED/ 1/2CASED & COLOURLESS & 25.3 & 6.58 & 20 & 0 & 30.77 \\
\hline 2 & ORITA & $06^{0} 52^{\prime} 53.2^{\prime \prime}$ & 6.88144 & $002^{0} 59^{\prime} 46.9^{\prime \prime}$ & 2.99636 & 6 & 0.25 & 5.74 & COVERED/ 1/2CASED & COLOURLESS & 27.5 & 7.14 & 22 & 0 & 33.85 \\
\hline 3 & ORITA & $06^{0} 52^{\prime} 51.2^{\prime \prime}$ & 6.88089 & $002^{0} 59^{\prime} 46.7^{\prime \prime}$ & 2.99631 & 7.5 & 1.34 & 6.16 & COVERED/ 1/2CASED & COLOURLESS & 27.4 & 7.04 & 38 & 0 & 58.46 \\
\hline 4 & ORITA & $06^{0} 52^{\prime} 50.5^{\prime \prime}$ & 6.88069 & $002^{0} 59^{\prime} 46.0^{\prime \prime}$ & 2.99611 & 7.8 & 0.67 & 7.13 & COVERED/ 1/2CASED & COLOURLESS & 29 & 6.64 & 11 & 0 & 16.92 \\
\hline 5 & ORITA & $06^{0} 52^{\prime} 50.1^{\prime \prime}$ & 6.88658 & $002^{0} 59^{\prime} 47.8^{\prime \prime}$ & 2.99661 & 4.22 & 1.22 & 3 & COVERED/CASED & COLOURLESS & 28.5 & 7.15 & 51 & 0 & 78.46 \\
\hline 6 & ORITA & $06^{0} 52^{\prime} 47.2^{\prime \prime}$ & 6.87978 & $002^{0} 59^{\prime} 45.9^{\prime \prime}$ & 2.99608 & 6.7 & 1.1 & 5.6 & COVERED/ 1/2CASED & COLOURLESS & 28.5 & 7.22 & 21 & 0 & 32.31 \\
\hline 7 & ORITA & $06^{0} 52^{\prime} 45.7^{\prime \prime}$ & 6.87936 & $002^{0} 59^{\prime} 46.9^{\prime \prime}$ & 2.99636 & 5.3 & 1.4 & 3.9 & COVERED/CASED & COLOURLESS & 29.1 & 6.97 & 25 & 0 & 38.46 \\
\hline 8 & ORITA & $06^{0} 52^{\prime} 46.5^{\prime \prime}$ & 6.87958 & $002^{0} 59^{\prime} 47.7^{\prime \prime}$ & 2.99658 & 3 & 0.57 & 2.43 & COVERED/CASED & COLOURLESS & 27.8 & 6.49 & 14 & 0 & 21.54 \\
\hline 9 & ORITA & $06^{0} 52^{\prime} 44.0^{\prime \prime}$ & 6.87889 & $002^{0} 59^{\prime} 44.2^{\prime \prime}$ & 2.99561 & 6.7 & 1.25 & 5.45 & COVERED/ 1/2CASED & COLOURLESS & 28.1 & 6.82 & 28 & 0 & 43.08 \\
\hline 10 & ORITA & $06^{0} 53^{\prime} 07.5^{\prime \prime}$ & 6.88542 & $002^{0} 59^{\prime} 53.9^{\prime \prime}$ & 2.99831 & 20.65 & 0.79 & 19.86 & COVERED/UNCASED & COLOURLESS & 27.4 & 6.61 & 33 & 0 & 50.7 \\
\hline 11 & ORITA & $06^{0} 53^{\prime} 06.7^{\prime \prime}$ & 6.88519 & $002^{0} 59^{\prime} 54.4^{\prime \prime}$ & 2.99844 & 20.15 & 0.93 & 19.22 & COVERED/UNCASED & BROWNISH & 26.9 & 6.35 & 43 & 0 & 66.15 \\
\hline 12 & ORITA & $06^{0} 53^{\prime} 08.5^{\prime \prime}$ & 6.88569 & $002^{0} 59^{\prime} 55.1^{\prime \prime}$ & 2.99864 & 20.22 & 0.67 & 20.25 & COVERED/UNCASED & COLOURLESS & 27.2 & 6.21 & 47 & 0 & 72.31 \\
\hline 13 & ORITA & $06^{0} 53^{\prime} 04.8^{\prime \prime}$ & 6.88467 & $002^{0} 59^{\prime} 55.2^{\prime \prime}$ & 2.99867 & 14 & 1.1 & 12.9 & COVERED/UNCASED & COLOURLESS & 26.15 & 6.08 & 36 & 0 & 55.38 \\
\hline 14 & ORITA & $06^{0} 53^{\prime} 03.9^{\prime \prime}$ & 6.88442 & $002^{0} 59^{\prime} 53.6^{\prime \prime}$ & 2.99822 & 15.68 & 0.73 & 14.95 & COVERED/UNCASED & COLOURLESS & 26.9 & 6.02 & 31 & 0 & 47.69 \\
\hline 15 & ORITA & $06^{0} 53^{\prime} 02.0^{\prime \prime}$ & 6.88389 & $002^{0} 59^{\prime} 55.1^{\prime \prime}$ & 2.99864 & 18.48 & 1.11 & 17.37 & COVERED/UNCASED & COLOURLESS & 28 & 6.32 & 4 & 0 & 6.15 \\
\hline 16 & ORITA & $06^{0} 53^{\prime} 02.4^{\prime \prime}$ & 6.88400 & $002^{0} 59^{\prime} 58.0^{\prime \prime}$ & 2.99944 & 16.43 & 1.18 & 15.25 & COVERED/UNCASED & COLOURLESS & 27.2 & 6.24 & 58 & 0 & 89.23 \\
\hline 17 & ORITA & $06^{0} 53^{\prime} 01.1^{\prime \prime}$ & 6.88364 & $002^{0} 59^{\prime} 57.1^{\prime \prime}$ & 2.99919 & 14.3 & 0.3 & 14 & COVERED/1/2CASED & COLOURLESS & 27.1 & 6.32 & 72 & 0 & 128.57 \\
\hline 18 & ORITA & $06^{0} 52^{\prime} 58.5^{\prime \prime}$ & 6.88292 & $002^{0} 59^{\prime} 57.2^{\prime \prime}$ & 2.99922 & 13.4 & 1.37 & 12.03 & COVERED/ 1/2CASED & COLOURLESS & 27 & 6.21 & 21 & 0 & 32.31 \\
\hline 19 & ORITA & $06^{0} 52^{\prime} 58.2^{\prime \prime}$ & 6.88283 & $002^{0} 59^{\prime} 58.2^{\prime \prime}$ & 2.99950 & 13.65 & 1.25 & 12.4 & COVERED/ 1/2CASED & COLOURLESS & 26.7 & 6.2 & 59 & 0 & 90.77 \\
\hline 20 & ORITA & $06^{0} 52^{\prime} 56.4^{\prime \prime}$ & 6.88233 & $002^{0} 59^{\prime} 57.3^{\prime \prime}$ & 2.99925 & 9.93 & 0.38 & 9.55 & COVERED/ 1/2CASED & COLOURLESS & 26.6 & 6.62 & 12 & 0 & 18.46 \\
\hline 21 & ORITA & $06^{0} 53^{\prime} 34.8^{\prime \prime}$ & 6.89300 & $002^{0} 59^{\prime} 48.2^{\prime \prime}$ & 2.99672 & 16.5 & 1.54 & 14.96 & COVERED/UNCASED & COLOURLESS & 28.7 & 6.22 & 30 & 0 & 46.15 \\
\hline 22 & ORITA & $06^{0} 53^{\prime} 35.2^{\prime \prime}$ & 6.89311 & $002^{0} 59^{\prime} 46.7^{\prime \prime}$ & 2.99631 & 17.03 & 1.73 & 15.3 & COVERED/UNCASED & COLOURLESS & 27.8 & 6.15 & 24 & 0 & 36.92 \\
\hline 23 & ORITA & $06^{0} 53^{\prime} 01.1^{\prime \prime}$ & 6.88364 & $002^{0} 59^{\prime} 46.9^{\prime \prime}$ & 2.99636 & 17.9 & 1.2 & 6.7 & COVERED/UNCASED & COLOURLESS & 28.2 & 8.83 & 73 & 0 & 112.31 \\
\hline 24 & ORITA & $06^{0} 52^{\prime} 59.2^{\prime \prime}$ & 6.88311 & $002^{0} 59^{\prime} 46.6^{\prime \prime}$ & 2.99628 & 5.81 & 0.26 & 5.45 & COVERED/UNCASED & COLOURLESS & 27.8 & 7.59 & 61 & 0 & 93.5 \\
\hline 25 & ORITA & $06^{0} 53^{\prime} 07.4^{\prime \prime}$ & 6.88539 & $002^{0} 59^{\prime} 52.8^{\prime \prime}$ & 2.99800 & 19.94 & 1.1 & 18.84 & UNCOVERED/ 1/2CASED & COLOURLESS & 27.5 & 6.39 & 31 & 0 & 47.69 \\
\hline 26 & ORITA & $06^{0} 52^{\prime} 56.4^{\prime \prime}$ & 6.88233 & $002^{0} 59^{\prime} 56.9^{\prime \prime}$ & 2.99914 & 10.45 & 0.98 & 9.47 & COVERED/ 1/2CASED & COLOURLESS & 28.9 & 6.6 & 14 & 0 & 21.54 \\
\hline 27 & ORITA KPAI & $06^{0} 53^{\prime} 20.8^{\prime \prime}$ & 6.88911 & $002^{0} 59^{\prime} 51.8^{\prime \prime}$ & 2.99772 & 32.63 & 1.71 & 30.92 & COVERED/UNCASED & COLOURLESS & 23.6 & 6.82 & 6 & 0 & 9.23 \\
\hline 28 & ORITA KPAI & $06^{0} 53^{\prime} 18.7^{\prime \prime}$ & 6.88853 & $002^{0} 59^{\prime} 53.8^{\prime \prime}$ & 2.99828 & 32.18 & 5.58 & 26.6 & COVERED/UNCASED & COLOURLESS & 21.8 & 6.55 & 6 & 0 & 9.23 \\
\hline 29 & ORITA KPAI & $06^{0} 53^{\prime} 18.3^{\prime \prime}$ & 6.88842 & $002^{0} 59^{\prime} 55.3^{\prime \prime}$ & 2.99869 & 31.9 & 1.8 & 30.1 & COVERED/UNCASED & COLOURLESS & 22.3 & 6.59 & 6 & 0 & 9.23 \\
\hline 30 & ORITA KPAI & $06^{0} 53^{\prime} 14.8^{\prime \prime}$ & 6.88744 & $002^{0} 59^{\prime} 54.7^{\prime \prime}$ & 2.99853 & 23.2 & 1.9 & 21.3 & COVERED/UNCASED & COLOURLESS & 22.1 & 6.58 & 6 & 0 & 9.23 \\
\hline 31 & ORITA KPAI & $06^{0} 53^{\prime} 12.1^{\prime \prime}$ & 6.88669 & $002^{0} 59^{\prime} 54.8^{\prime \prime}$ & 2.99856 & 25.92 & 3.42 & 22.5 & COVERED/UNCASED & COLOURLESS & 22.3 & 6.52 & 6 & 0 & 9.23 \\
\hline 32 & ORITA KPAI & $06^{0} 53^{\prime} 12.1^{\prime \prime}$ & 6.88669 & $002^{0} 59^{\prime} 54.2^{\prime \prime}$ & 2.99839 & 26.1 & 2.1 & 24 & COVERED/UNCASED & COLOURLESS & 22.5 & 6.41 & 6 & 0 & 9.23 \\
\hline 33 & ORITA KPAI & $06^{0} 53^{\prime} 04.1^{\prime \prime}$ & 6.88447 & $002^{0} 59^{\prime} 57.1^{\prime \prime}$ & 2.99919 & 18.98 & 0.93 & 18.05 & UNCOVERED/UNCASED & COLOURLESS & 27.5 & 6.41 & 28 & 0 & 43.08 \\
\hline 34 & ORITA TREM & $06^{0} 53^{\prime} 05.0^{\prime \prime}$ & 6.88472 & $002^{0} 59^{\prime} 56.1^{\prime \prime}$ & 2.99892 & 19.18 & 1.18 & 18 & COVERED/UNCASED & COLOURLESS & 27.4 & 6.33 & 11 & 0 & 16.92 \\
\hline 35 & EXPRESS & $06^{0} 53^{\prime} 06.0^{\prime \prime}$ & 6.88500 & $002^{0} 59^{\prime} 47.0^{\prime \prime}$ & 2.99639 & 23.85 & 1.35 & 22.5 & COVERED/UNCASED & COLOURLESS & 27 & 6.98 & 24 & 0 & 36.92 \\
\hline 36 & EXPRESS & $06^{0} 53^{\prime} 13.3^{\prime \prime}$ & 6.88703 & $003^{0} 00^{\prime} 30.3^{\prime \prime}$ & 2.99175 & 3.68 & 1.42 & 2.26 & COVERED/CASED & COLOURLESS & 26.1 & 6.63 & 62 & 0 & 95.38 \\
\hline 37 & EXPRESS & $06^{0} 53^{\prime} 11.8^{\prime \prime}$ & 6.88661 & $002^{0} 59^{\prime} 41.8^{\prime \prime}$ & 2.99494 & 34.21 & 2.09 & 32.12 & COVERED/UNCASED & COLOURLESS & 24.4 & 6.67 & 6 & 0 & 9.23 \\
\hline 38 & EXPRESS & $06^{0} 53^{\prime} 16.5^{\prime \prime}$ & 6.88817 & $002^{0} 59^{\prime} 45.4^{\prime \prime}$ & 2.99519 & 33.35 & 1.67 & 31.69 & COVERED/UNCASED & COLOURLESS & 26.8 & 6.52 & 96 & 0 & 147.69 \\
\hline 39 & EXPRESS & $06^{0} 53^{\prime} 17.4^{\prime \prime}$ & 6.87822 & $002^{0} 59^{\prime} 42.7^{\prime \prime}$ & 2.99581 & 33 & 1.15 & 31.85 & COVERED/UNCASED & COLOURLESS & 26.3 & 6.74 & 6 & 0 & 9.23 \\
\hline 40 & GBOGIDI & $06^{0} 52^{\prime} 41.6^{\prime \prime}$ & 6.87869 & $002^{0} 59^{\prime} 44.9^{\prime \prime}$ & 2.99639 & 5.45 & 2.25 & 3.2 & COVERED/CASED & COLOURLESS & 28.9 & 7.1 & 49 & 0 & 75.38 \\
\hline 41 & GBOGIDI & $06^{0} 52^{\prime} 43.3^{\prime \prime}$ & 6.87828 & $002^{0} 59^{\prime} 47.0^{\prime \prime}$ & 2.99797 & 3.07 & 1.17 & 1.9 & COVERED/CASED & COLOURLESS & 26.8 & 7.23 & 39 & 0 & 60 \\
\hline 42 & GBOGIDI & $06^{0} 52^{\prime} 41.8^{\prime \prime}$ & 6.87797 & $002^{0} 59^{\prime} 52.7^{\prime \prime}$ & 2.99800 & 4.61 & 2.13 & 2.48 & COVERED/CASED & COLOURLESS & 29 & 5.98 & 73 & 0 & 112.31 \\
\hline
\end{tabular}




\begin{tabular}{|c|c|c|c|c|c|c|c|c|c|c|c|c|c|c|c|}
\hline$S / N$ & LOCATION & LATITUDE & NORTHINGS & LONGITUDE & EASTINGS & $\begin{array}{c}\text { WELL } \\
\text { DEPTH } \\
(\mathrm{m})\end{array}$ & $\begin{array}{c}\text { WATER } \\
\text { LEVEL (m) }\end{array}$ & $\begin{array}{c}\text { WELL } \\
\text { HEAD } \\
\text { (m) }\end{array}$ & $\begin{array}{c}\text { CONDITION OF THE } \\
\text { WELL }\end{array}$ & COLOUR & $\begin{array}{c}\text { TEMPERATURE } \\
\left({ }^{\circ} \mathrm{C}\right)\end{array}$ & $\mathrm{PH}$ & TDS & $\begin{array}{l}\text { SALINITY } \\
(\%)\end{array}$ & $\begin{array}{l}\text { ELECTRICAL } \\
\text { CONDUCTIVITY }\end{array}$ \\
\hline 43 & GBOGIDI & $06^{0} 52^{\prime} 40.9^{\prime \prime}$ & 6.87756 & $002^{0} 59^{\prime} 52.8^{\prime \prime}$ & 2.99781 & 2.6 & 0.55 & 2.05 & COVERED/UNCASED & WHITISH & 28 & 6.82 & 109 & 0.01 & 167.69 \\
\hline 44 & GBOGIDI & $06^{0} 52^{\prime} 39.2^{\prime \prime}$ & 6.87678 & $002^{0} 59^{\prime} 52.1^{\prime \prime}$ & 2.99758 & 2.52 & 0.94 & 1.58 & UNCOVERED/UNCASED & WHITISH & 28 & 7.04 & 111 & 0.01 & 170.77 \\
\hline 45 & GBOGIDI & $06^{0} 52^{\prime} 36.4^{\prime \prime}$ & 6.87653 & $002^{0} 59^{\prime} 51.3^{\prime \prime}$ & 2.99758 & 4.15 & 2.51 & 1.64 & COVERED/CASED & COLOURLESS & 27.4 & 6.42 & 49 & 0 & 75.38 \\
\hline 46 & GBOGIDI & $06^{0} 52^{\prime} 35.5^{\prime \prime}$ & 6.87625 & $002^{0} 59^{\prime} 51.3^{\prime \prime}$ & 2.99761 & 1.54 & 1.04 & 0.5 & COVERED/CASED & COLOURLESS & 26 & 7.23 & 185 & 0.01 & 284.62 \\
\hline 47 & GBOGIDI & $06^{0} 52^{\prime} 34.5^{\prime \prime}$ & 6.87583 & $002^{0} 59^{\prime} 51.4^{\prime \prime}$ & 2.99772 & 3.32 & 2.18 & 1.14 & COVERED/CASED & COLOURLESS & 27.1 & 6.23 & 50 & 0 & 76.92 \\
\hline 48 & GBOGIDI & $06^{0} 52^{\prime} 33.0^{\prime \prime}$ & 6.87567 & $002^{0} 59^{\prime} 51.8^{\prime \prime}$ & 2.99794 & 2.95 & 1.51 & 1.44 & UNCOVERED/CASED & COLOURLESS & 27.5 & 6.8 & 104 & 0.01 & 160 \\
\hline 49 & GBOGIDI & $06^{0} 52^{\prime} 32.4^{\prime \prime}$ & 6.87544 & $002^{0} 59^{\prime} 52.6^{\prime \prime}$ & 2.99844 & 2.67 & 1.12 & 1.55 & UNCOVERED/CASED & GREYISH & 26.7 & 7.53 & 82 & 0 & 126.15 \\
\hline 50 & GBOGIDI & $06^{0} 52^{\prime} 31.6^{\prime \prime}$ & 6.87547 & $002^{0} 59^{\prime} 54.4^{\prime \prime}$ & 2.99869 & 3.45 & 1.95 & 1.5 & UNCOVERED/CASED & BROWNISH & 28.7 & 6.89 & 71 & 0 & 109.23 \\
\hline 51 & GBOGIDI & $06^{0} 52^{\prime} 31.7^{\prime \prime}$ & 6.87575 & $002^{0} 59^{\prime} 55.3^{\prime \prime}$ & 2.99902 & 4.4 & 3.2 & 1.2 & UNCOVERED/CASED & BROWNISH & 28.2 & 7.01 & 62 & 0 & 95.38 \\
\hline 52 & GBOGIDI & $06^{0} 52^{\prime} 32.7^{\prime \prime}$ & 6.87636 & $002^{0} 59^{\prime} 56.5^{\prime \prime}$ & 2.99964 & 2.85 & 0.95 & 1.9 & COVERED/CASED & COLOURLESS & 28 & 6.38 & 76 & 0 & 116.92 \\
\hline 53 & GBOGIDI & $06^{0} 52^{\prime} 34.9^{\prime \prime}$ & 6.87647 & $002^{0} 59^{\prime} 58.7^{\prime \prime}$ & 2.99989 & 2.61 & 1.01 & 1.6 & UNCOVERED/CASED & COLOURLESS & 28.9 & 6.34 & 115 & 0.01 & 176.92 \\
\hline 54 & GBOGIDI & $06^{0} 52^{\prime} 35.3^{\prime \prime}$ & 6.87600 & $002^{0} 59^{\prime} 59.6^{\prime \prime}$ & 3.00019 & 1.74 & 0.8 & 0.94 & COVERED/CASED & COLOURLESS & 27 & 6.51 & 117 & 0.01 & 180 \\
\hline 55 & GBOGIDI & $06^{0} 52^{\prime 2} 33.6^{\prime \prime}$ & 6.87619 & $003^{\circ} 00^{\prime} 00.7^{\prime \prime}$ & 3.00064 & 3.64 & 2.44 & 1.2 & UNCOVERED/CASED & COLOURLESS & 26.6 & 6.89 & 137 & 0.01 & 210.77 \\
\hline 56 & GBOGIDI & $06^{0} 52^{\prime} 34.3^{\prime \prime}$ & 6.87667 & $003^{\circ} 00^{\prime} 02.3^{\prime \prime}$ & 3.00097 & 2.44 & 0.8 & 1.64 & UNCOVERED/CASED & COLOURLESS & 27.6 & 6.85 & 105 & 0.01 & 161.54 \\
\hline 57 & GBOGIDI & $06^{0} 52^{\prime} 36.0^{\prime \prime}$ & 6.87733 & $003^{0} 00^{\prime} 03.5^{\prime \prime}$ & 3.00142 & 3.3 & 1.4 & 1.9 & COVERED/CASED & COLOURLESS & 28.9 & 6.3 & 111 & 0.01 & 170.77 \\
\hline 58 & GBOGIDI & $06^{0} 52^{\prime} 38.4^{\prime \prime}$ & 6.87731 & $003^{\circ} 00^{\prime} 05.1^{\prime \prime}$ & 3.00047 & 4.3 & 1.35 & 2.95 & COVERED/UNCASED & COLOURLESS & 27.5 & 7.05 & 111 & 0 & 170.77 \\
\hline 59 & GBOGIDI & $06^{0} 52^{\prime} 38.3^{\prime \prime}$ & 6.87742 & $003^{\circ} 00^{\prime} 01.7^{\prime \prime}$ & 2.99994 & 5.1 & 1.2 & 3.9 & COVERED/CASED & COLOURLESS & 27 & 5.88 & 73 & 0 & 112.3 \\
\hline 60 & GBOGIDI & $06^{0} 52^{\prime} 38.7^{\prime \prime}$ & 6.87750 & $002^{0} 59^{\prime} 59.8^{\prime \prime}$ & 2.99975 & 5.55 & 1.8 & 3.75 & COVERED/CASED & COLOURLESS & 27 & 6.53 & 14 & 0 & 21.54 \\
\hline 61 & GBOGIDI & $06^{0} 52^{\prime} 39.0^{\prime \prime}$ & 6.87756 & $002^{0} 59^{\prime} 59.1^{\prime \prime}$ & 2.99967 & 5.3 & 1.59 & 3.71 & COVERED/CASED & COLOURLESS & 27.1 & 6.77 & 17 & 0 & 26.15 \\
\hline 62 & GBOGIDI & $06^{0} 52^{\prime} 39.2^{\prime \prime}$ & 6.87869 & $002^{0} 59^{\prime} 58.8^{\prime \prime}$ & 2.99833 & 4.22 & 0.97 & 3.25 & COVERED/CASED & COLOURLESS & 27.3 & 6.96 & 43 & 0 & 66.15 \\
\hline 63 & GBOGIDI & $06^{0} 52^{\prime} 43.3^{\prime \prime}$ & 6.87806 & $002^{\circ} 59^{\prime} 54.0^{\prime \prime}$ & 3.00161 & 5.7 & 2.48 & 3.22 & COVERED/UNCASED & COLOURLESS & 27.2 & 6.09 & 41 & 0 & 63.08 \\
\hline 64 & GBOGIDI & $06^{0} 52^{\prime} 41.0^{\prime \prime}$ & 6.87706 & $003^{\circ} 00^{\prime} 05.8^{\prime \prime}$ & 3.00275 & 6.15 & 1.81 & 4.34 & COVERED/CASED & COLOURLESS & 29 & 6.82 & 13 & 0 & 20 \\
\hline 65 & GBOGIDI & $06^{0} 52^{\prime} 37.4^{\prime \prime}$ & 6.87658 & $003^{0} 00^{\prime} 09.9^{\prime \prime}$ & 3.00356 & 4.05 & 1.62 & 2.43 & COVERED/CASED & BROWNISH & 22 & 7.31 & 23 & 0 & 35.38 \\
\hline 66 & GBOGIDI & $06^{0} 52^{\prime} 35.7^{\prime \prime}$ & 6.87728 & $003^{0} 00^{\prime} 12.8^{\prime \prime}$ & 3.00403 & 3.56 & 1.16 & 2.4 & UNCOVERED/CASED & BROWNISH & 23.5 & 7.52 & 23 & 0 & 35.38 \\
\hline 67 & GBOGIDI & $06^{0} 52^{\prime} 38.2^{\prime \prime}$ & 6.87800 & $003^{0} 00^{\prime} 14.5^{\prime \prime}$ & 3.00503 & 3.09 & 1.85 & 1.24 & UNCOVERED/CASED & COLOURLESS & 23.5 & 7.6 & 48 & 0 & 73.85 \\
\hline 68 & GBOGIDI & $06^{0} 52^{\prime} 40.8^{\prime \prime}$ & 6.87769 & $003^{0} 00^{\prime} 18.1^{\prime \prime}$ & 3.00531 & 3.34 & 1.3 & 2.04 & COVERED/CASED & COLOURLESS & 21.1 & 7.97 & 38 & 0 & 58.46 \\
\hline 69 & GBOGIDI & $06^{0} 52^{\prime} 39.7^{\prime \prime}$ & 6.87794 & $003^{0} 00^{\prime} 19.1^{\prime \prime}$ & 3.00669 & 3.49 & 1.36 & 2.13 & COVERED/CASED & COLOURLESS & 20.6 & 8.18 & 24 & 0 & 36.92 \\
\hline 70 & GBOGIDI & $06^{0} 52^{\prime} 40.6^{\prime \prime}$ & 6.87750 & $003^{\circ} 00^{\prime} 24.1^{\prime \prime}$ & 3.00611 & 10.1 & 0.6 & 9.5 & COVERED/1/2CASED & COLOURLESS & 24.5 & 5.35 & 20 & 0 & 30.77 \\
\hline 71 & GBOGIDI & $06^{0} 52^{\prime} 39.0^{\prime \prime}$ & 6.87731 & $003^{0} 00^{\prime} 22.0^{\prime \prime}$ & 3.00658 & 4.13 & 1.83 & 2.3 & COVERED/UNCASED & COLOURLESS & 22.3 & 7.24 & 54 & 0 & 83.08 \\
\hline 72 & GBOGIDI & $06^{0} 52^{\prime 2} 38.3^{\prime \prime}$ & 6.87750 & $003^{0} 00^{\prime 2} 23.7^{\prime \prime}$ & 3.00719 & 5.65 & 0.9 & 4.75 & COVERED/UNCASED & COLOURLESS & 20.8 & 7.19 & 49 & 0 & 75.38 \\
\hline 73 & GBOGIDI & $06^{0} 52^{\prime} 39.0^{\prime \prime}$ & 6.87750 & $003^{0} 00^{\prime} 25.9^{\prime \prime}$ & 3.00742 & 9.12 & 0.82 & 8.3 & COVERED/1/2CASED & COLOURLESS & 24.3 & 5.52 & 18 & 0 & 27.69 \\
\hline 74 & GBOGIDI & $06^{0} 52^{\prime} 39.0^{\prime \prime}$ & 6.87947 & $003^{0} 00^{\prime} 26.7^{\prime \prime}$ & 2.99853 & 10.03 & 0.88 & 9.15 & COVERED/1/2CASED & COLOURLESS & 26.8 & 6.51 & 20 & 0 & 30.77 \\
\hline 75 & GBOGIDI & $06^{0} 52^{\prime} 46.1^{\prime \prime}$ & 6.88000 & $002^{0} 59^{\prime} 54.7^{\prime \prime}$ & 2.99844 & 4.2 & 1 & 3.2 & COVERED/1/2CASED & COLOURLESS & 27.8 & 6.4 & 38 & 0 & 58.46 \\
\hline 76 & GBOGIDI & $06^{0} 52^{\prime} 48.0^{\prime \prime}$ & 6.88003 & $002^{0} 59^{\prime} 54.4^{\prime \prime}$ & 2.99800 & 5.22 & 0.88 & 4.34 & COVERED/CASED & COLOURLESS & 28.1 & 5.94 & 44 & 0 & 67.69 \\
\hline 77 & GBOGIDI & $06^{0} 52^{\prime} 48.1^{\prime \prime}$ & 6.88253 & $002^{0} 59^{\prime} 52.8^{\prime \prime}$ & 2.99822 & 6.6 & 2.41 & 4.19 & COVERED/CASED & COLOURLESS & 28.3 & 6.1 & 39 & 0 & 60 \\
\hline 78 & GBOGIDI & $06^{0} 52^{\prime} 57.1^{\prime \prime}$ & 6.88142 & $002^{0} 59^{\prime} 53.6^{\prime \prime}$ & 2.99892 & 6.75 & 2.1 & 4.65 & COVERED/CASED & COLOURLESS & 28 & 6.16 & 42 & 0 & 64.62 \\
\hline 79 & GBOGIDI & $06^{0} 52^{\prime} 53.1^{\prime \prime}$ & 6.88106 & $002^{0} 59^{\prime} 56.1^{\prime \prime}$ & 2.99908 & 5.15 & 1.45 & 3.7 & COVERED/1/2CASED & COLOURLESS & 26 & 6.39 & 6 & 0 & 9.23 \\
\hline 80 & GBOGIDI & $06^{0} 52^{\prime} 51.8^{\prime \prime}$ & 6.88094 & $002^{0} 59^{\prime} 56.7^{\prime \prime}$ & 2.99864 & 3.8 & 1.55 & 2.25 & COVERED/CASED & COLOURLESS & 25.9 & 6.6 & 6 & 0 & 9.23 \\
\hline 81 & GBOGIDI & $06^{0} 52^{\prime} 51.4^{\prime \prime}$ & 6.88044 & $002^{0} 59^{\prime} 55.1^{\prime \prime}$ & 2.99889 & 6.2 & 1.5 & 4.7 & COVERED/CASED & COLOURLESS & 26.7 & 6.55 & 6 & 0 & 9.23 \\
\hline 82 & GBOGIDI & $06^{0} 52^{\prime} 49.6^{\prime \prime}$ & 6.87625 & $002^{0} 59^{\prime} 56.0^{\prime \prime}$ & 3.00539 & 4.1 & 2.02 & 2.08 & COVERED/CASED & BROWNISH & 25.5 & 7.04 & 7 & 0 & 10.76 \\
\hline
\end{tabular}


SPATIAL SCHEME FOR GROUNDWATER FLOW AND DISTRIBUTION IN ILARO, SOUTHWESTERN NIGERIA,

N. O. Adebisi, et al

\begin{tabular}{|c|c|c|c|c|c|c|c|c|c|c|c|c|c|c|c|}
\hline$S / N$ & LOCATION & LATITUDE & NORTHINGS & LONGITUDE & EASTINGS & $\begin{array}{l}\text { WELL } \\
\text { DEPTH } \\
(\mathrm{m})\end{array}$ & $\begin{array}{c}\text { WATER } \\
\operatorname{LEVEL}(\mathrm{m})\end{array}$ & $\begin{array}{l}\text { WELL } \\
\text { HEAD } \\
(\mathrm{m})\end{array}$ & $\begin{array}{c}\text { CONDITION OF THE } \\
\text { WELL }\end{array}$ & COLOUR & $\begin{array}{c}\text { TEMPERATURE } \\
\left({ }^{\circ} \mathrm{C}\right)\end{array}$ & $\mathrm{PH}$ & TDS & $\begin{array}{c}\text { SALINITY } \\
(\%)\end{array}$ & $\begin{array}{l}\text { ELECTRICAL } \\
\text { CONDUCTIVITY }\end{array}$ \\
\hline 83 & GBOGIDI & $06^{0} 52^{\prime} 34.5^{\prime \prime}$ & 6.88808 & $003^{0} 00^{\prime} 19.4^{\prime \prime}$ & 3.01494 & 5.15 & 2.65 & 2.5 & COVERED/CASED & BROWNISH & 27 & 6.79 & 184 & 0.01 & 283.08 \\
\hline 84 & $\begin{array}{l}\text { LOWER } \\
\text { MISSION }\end{array}$ & $06^{0} 53^{\prime} 17.1^{\prime \prime}$ & 6.88700 & $003^{0} 00^{\prime} 53.8^{\prime \prime}$ & 3.01389 & 14.27 & 0.59 & 13.68 & COVERED/CASED & COLOURLESS & 24.2 & 6.58 & 9 & 0 & 13.85 \\
\hline 85 & $\begin{array}{l}\text { LOWER } \\
\text { MISSION }\end{array}$ & $06^{0} 53^{\prime} 13.2^{\prime \prime}$ & 6.88575 & $003^{0} 00^{\prime} 50.0^{\prime \prime}$ & 3.01367 & 15 & 1 & 14 & COVERED/UNCASED & COLOURLESS & 23.3 & 5.11 & 6 & 0 & 9.23 \\
\hline 86 & $\begin{array}{l}\text { LOWER } \\
\text { MISSION }\end{array}$ & $06^{0} 53^{\prime} 08.7^{\prime \prime}$ & 6.88581 & $003^{0} 00^{\prime} 49.2^{\prime \prime}$ & 3.01364 & 12.54 & 0.97 & 11.75 & COVERED/UNCASED & COLOURLESS & 22.4 & 6.25 & 21 & 0 & 32.31 \\
\hline 87 & $\begin{array}{l}\text { LOWER } \\
\text { MISSION }\end{array}$ & $06^{0} 53^{\prime} 08.9^{\prime \prime}$ & 6.88378 & $003^{\circ} 00^{\prime} 49.1^{\prime \prime}$ & 3.01328 & 13.15 & 1.05 & 12.1 & COVERED/UNCASED & COLOURLESS & 22.3 & 6.3 & 23 & 0 & 35.38 \\
\hline 88 & $\begin{array}{l}\text { LOWER } \\
\text { MISSION }\end{array}$ & $06^{0} 53^{\prime} 01.6^{\prime \prime}$ & 6.88408 & $003^{0} 00^{\prime} 47.8^{\prime \prime}$ & 3.01344 & 11.5 & 2.27 & 9.23 & COVERED/UNCASED & COLOURLESS & 23.2 & 5.63 & 10 & 0 & 15.38 \\
\hline 89 & $\begin{array}{l}\text { LOWER } \\
\text { MISSION }\end{array}$ & $06^{0} 53^{\prime} 02.7^{\prime \prime}$ & 6.88522 & $003^{\circ} 00^{\prime} 48.4^{\prime \prime}$ & 3.01381 & 10.09 & 1.5 & 8.59 & COVERED/UNCASED & COLOURLESS & 23.7 & 6.35 & 6 & 0 & 9.23 \\
\hline 90 & AJEGUNLE & $06^{0} 53^{\prime} 06.8^{\prime \prime}$ & 6.88483 & $003^{0} 00^{\prime} 49.7^{\prime \prime}$ & 3.01375 & 8.92 & 0.71 & 8.21 & COVERED/UNCASED & COLOURLESS & 22.3 & 4.75 & 10 & 0 & 15.38 \\
\hline 91 & AJEGUNLE & $06^{0} 53^{\prime} 05.4^{\prime \prime}$ & 6.88483 & $003^{0} 00^{\prime} 49.5^{\prime \prime}$ & 3.01403 & 8.99 & 0.99 & 8 & COVERED/UNCASED & COLOURLESS & 22.9 & 5.06 & 60 & 0 & 92.3 \\
\hline 92 & AJEGUNLE & $06^{0} 53^{\prime} 05.5^{\prime \prime}$ & 6.88478 & $003^{0} 00^{\prime} 50.5^{\prime \prime}$ & 3.01403 & 7.8 & 0.9 & 6.9 & COVERED/UNCASED & COLOURLESS & 26.6 & 4.89 & 91 & 0 & 140 \\
\hline 93 & AJEGUNLE & $06^{0} 53^{\prime} 05.2^{\prime \prime}$ & 6.88506 & $003^{0} 00^{\prime} 50.5^{\prime \prime}$ & 3.01403 & 6.9 & 0.8 & 6.1 & COVERED/UNCASED & COLOURLESS & 25.9 & 4.96 & 98 & 0 & 150.77 \\
\hline 94 & AJEGUNLE & $06^{0} 53^{\prime} 06.2^{\prime \prime}$ & 6.88556 & $003^{0} 00^{\prime} 50.5^{\prime \prime}$ & 3.01431 & 8.3 & 1.45 & 6.85 & COVERED/1/2CASED & COLOURLESS & 26.6 & 5.07 & 82 & 0 & 126.15 \\
\hline 95 & ARAROMI & $06^{0} 53^{\prime} 08.0^{\prime \prime}$ & 6.88539 & $003^{0} 00^{\prime} 51.5^{\prime \prime}$ & 3.01433 & 7.7 & 0.6 & 7.1 & COVERED/UNCASED & COLOURLESS & 25.3 & 5.23 & 91 & 0 & 140 \\
\hline 96 & ARAROMI & $06^{0} 53^{\prime} 07.4^{\prime \prime}$ & 6.88575 & $003^{0} 00^{\prime} 51.6^{\prime \prime}$ & 3.01414 & 7.65 & 1.3 & 6.35 & COVERED/1/2CASED & COLOURLESS & 26.3 & 6.13 & 60 & 0 & 92.3 \\
\hline 97 & ARAROMI & $06^{0} 53^{\prime} 08.7^{\prime \prime}$ & 6.83350 & $003^{0} 00^{\prime} 50.9^{\prime \prime}$ & 3.01456 & 5.91 & 2.68 & 3.23 & UNCOVERED/UNCASED & BROWNISH & 24.5 & 4.74 & 58 & 0 & 89.23 \\
\hline 98 & ARAROMI & $06^{0} 53^{\prime} 06.0^{\prime \prime}$ & 6.88536 & $003^{0} 00^{\prime} 52.4^{\prime \prime}$ & 3.01461 & 7.93 & 2.73 & 5.2 & COVERED/UNCASED & COLOURLESS & 25.9 & 6.18 & 63 & 0 & 96.92 \\
\hline 99 & ARAROMI & $06^{0} 53^{\prime} 07.3^{\prime \prime}$ & 6.88458 & $003^{0} 00^{\prime} 52.6^{\prime \prime}$ & 3.01428 & 9.12 & 0.79 & 8.33 & COVERED/UNCASED & COLOURLESS & 25 & 5.06 & 111 & 0 & 170.77 \\
\hline 100 & ARAROMI & $06^{0} 53^{\prime} 04.5^{\prime \prime}$ & 6.88456 & $003^{0} 00^{\prime} 51.4^{\prime \prime}$ & 3.01422 & 10.25 & 1.94 & 8.31 & COVERED/CASED & COLOURLESS & 26.3 & 6.81 & 63 & 0 & 96.92 \\
\hline 101 & ARAROMI & $06^{0} 53^{\prime} 04.4^{\prime \prime}$ & 6.88403 & $003^{0} 00^{\prime} 51.2^{\prime \prime}$ & 3.01431 & 12.32 & 1.27 & 11.05 & COVERED/UNCASED & COLOURLESS & 26.1 & 6.8 & 60 & 0 & 92.3 \\
\hline 102 & ARAROMI & $06^{0} 53^{\prime} 02.0^{\prime \prime}$ & 6.88342 & $003^{0} 00^{\prime} 51.5^{\prime \prime}$ & 3.01408 & 9.95 & 1.75 & 8.2 & COVERED/CASED & COLOURLESS & 26.2 & 5.98 & 42 & 0 & 64.62 \\
\hline 103 & ARAROMI & $06^{0} 53^{\prime} 00.3^{\prime \prime}$ & 6.88311 & $003^{0} 00^{\prime} 50.7^{\prime \prime}$ & 3.01367 & 13.72 & 1.97 & 11.75 & UNCOVERED/CASED & COLOURLESS & 25.4 & 5.06 & 59 & 0 & 90.77 \\
\hline 104 & ARAROMI & $06^{0} 52^{\prime} 59.2^{\prime \prime}$ & 6.88300 & $003^{0} 00^{\prime} 49.2^{\prime \prime}$ & 3.01344 & 19.23 & 2.18 & 17.05 & COVERED/CASED & BROWNISH & 24.3 & 6.21 & 20 & 0 & 30.77 \\
\hline 105 & ARAROMI & $06^{0} 52^{\prime} 58.8^{\prime \prime}$ & 6.88264 & $003^{0} 00^{\prime} 48.4^{\prime \prime}$ & 3.01342 & 20.01 & 1.25 & 18.76 & COVERED/UNCASED & BROWNISH & 24 & 6.3 & 22 & 0 & 33.85 \\
\hline 106 & ARAROMI & $06^{0} 52^{\prime} 57.5^{\prime \prime}$ & 6.88272 & $003^{0} 00^{\prime} 48.3^{\prime \prime}$ & 3.01328 & 18.75 & 1.72 & 17.03 & COVERED/UNCASED & BROWNISH & 24.5 & 6.32 & 52 & 0 & 80 \\
\hline 107 & ARAROMI & $06^{0} 52^{\prime} 57.8^{\prime \prime}$ & 6.88289 & $003^{0} 00^{\prime} 47.8^{\prime \prime}$ & 3.01281 & 19.82 & 1.67 & 18.15 & COVERED/CASED & BROWNISH & 24.2 & 6.4 & 63 & 0 & 96.92 \\
\hline 108 & ARAROMI & $06^{0} 52^{\prime} 58.4^{\prime \prime}$ & 6.88500 & $003^{0} 00^{\prime} 46.1^{\prime \prime}$ & 3.01328 & 17.25 & 1.99 & 15.26 & COVERED/UNCASED & COLOURLESS & 26.2 & 7.08 & 45 & 0 & 69.23 \\
\hline 109 & ARAROMI & $06^{0} 53^{\prime} 06.0^{\prime \prime}$ & 6.88792 & $003^{0} 00^{\prime} 47.8^{\prime \prime}$ & 2.99594 & 25.2 & 2.2 & 23 & COVERED/CASED & COLOURLESS & 25.5 & 6.57 & 32 & 0 & 49.23 \\
\hline
\end{tabular}

